\title{
Bone Marrow Stromal Antigen 2
}

National Cancer Institute

\section{Source}

National Cancer Institute. Bone Marrow Stromal Antigen 2. NCI Thesaurus. Code

C154136.

Bone marrow stromal antigen $2(180 \mathrm{aa}, \sim 20 \mathrm{kDa})$ is encoded by the human BST 2 gene.

This protein is involved in preventing the release of virions from infected cells. 